\title{
Recenzje
}

DOI: $10.35757 /$ CIV.2012.14.11

\section{Zmieniająca się świadomość}

Justyna Miklaszewska, Jakub Szczepański (red.): Filozofia polityczna po roku 1989. Teoria - historia - praktyka, Wydawnictwo Uniwersytetu Jagiellońskiego, Kraków 2012, ss. 362.

Ksiażka Filozofia polityczna po roku 1989. Teoria - historia - praktyka, wydana przez Wydawnictwo Uniwersytetu Jagiellońskiego, to zbiór materiałów $z$ konferencji, która odbyła się $\mathrm{w}$ Instytucie Filozofii Uniwersytetu Jagiellońskiego w dniach 23-25 września 2010 roku (organizatorem spotkania był Zakład Historii Filozofii Instytutu Filozofii Uniwersytetu Jagiellońskiego we współpracy z Zakładem Filozofii Polityki Instytutu Filozofii Uniwersytetu Warszawskiego i Wydziałem Humanistycznym Uniwersytetu Mikołaja Kopernika w Toruniu). We wstępie redaktorzy naukowi tomu - prof. Justyna Miklaszewska i dr Jakub Szczepański - tak określili cel konferencji: „Minęło już ponad dwadzieścia lat po przełomowym zwrocie w najnowszej historii Polski, jaki dokonał się w 1989 roku, nadszedł więc czas, by polskie środowisko filozoficzne podjęło próbę zastanowienia się nad znaczeniem tego okresu dla współczesnej myśli politycznej"’.

1 J. Miklaszewska, J. Szczepański (red.): Filozofia polityczna po roku 1989. Teoria - historia - praktyka, Wydawnictwo Uniwersytetu Jagiellońskiego, Kraków 2012, s. 9. 
Powyższy cytat doskonale oddaje główną myśl recenzowanej publikacji. Motywem organizacji konferencji i opublikowania wygłoszonych na niej referatów jest próba zrozumienia i opisu zmian zachodzacych w kraju po 1989 roku. Choć w Polsce bardzo dużo się dyskutuje o tym, co nastapiło po upadku komunizmu, to jednak w zakresie rzeczywistej refleksji filozoficznej nie mamy raczej do czynienia $z$ nadmiarem prac. Analizy zawarte w publikacji Filozofia polityczna po roku 1989 staraja się podjać ten ważny temat, dotycza jednak przede wszystkim samej myśli politycznej - tego, jak próbowano ujmować zmieniająca się rzeczywistość w Polsce i na świecie. Warto podkreślić tę subtelną, lecz niezwykle istotna różnicę. Redaktorzy naukowi omawianego tomu, będący jednocześnie współorganizatorami konferencji, deklaruja, że głównym tematem publikacji nie jest analiza samych zdarzeń oraz przemian ustrojowych i gospodarczych zachodzacych w polskim społeczeństwie i polskiej polityce. Uwaga ma być skoncentrowana na przemianach w filozofii politycznej rozwijanej po 1989 roku. Uczestnicy konferencji mieli się bowiem skupić na zmianach na poziomie świadomości - zarówno ludzi zajmujących się zawodowo refleksja filozoficzna, jak i tzw. świadomości zbiorowej.

Całkowite oddzielenie obu tych płaszczyzn oczywiście nie jest możliwe, autorzy tekstów zebranych w omawianej publikacji nie skupiaja się więc wyłącznie na ewolucji idei. Opisując zmieniająca się świadomość, równolegle dokonuja analizy zdarzeń i ich konsekwencji. W ten sposób łączą refleksję na metapoziomie (dotycząca dawnego i obecnego rozumienia sfery polityki) $z$ namysłem bezpośrednio odwołującym się do świata, w którym żyjemy. Trzeba także dodać, że przynajmniej część uczestników konferencji nie skupiała się wyłącznie na przemianach zachodzacych jedynie w Polsce, interesowały ich bowiem problemy o znaczeniu globalnym, żywotne w filozofii politycznej we współczesnym świecie, dzięki temu także w Trzeciej Rzeczypospolitej. Redaktorzy podkreślaja, że wśród kilkunastu badaczy $z$ całej Polski są autorzy reprezentujacy różne pokolenia. Od nieco starszych, którzy współtworzyli procesy, jakie 
doprowadziły do zmian po 1989 roku, po młodych doktorantów, wychowanych już w wolnej Polsce. Różnorodność ta miała zapewnić wysoki poziom i wieloaspektowość krakowskiej konferencji.

Wszystkie teksty zebrane w recenzowanej publikacji zostały podzielone na trzy główne grupy: artykuły teoretyczno-filozoficzne, prace związane $z$ szeroko rozumiana historią filozofii politycznej i teksty nawiąujące bezpośrednio do praktyki niedawnych przemian politycznych.

Autorzy opracowań ujętych w pierwszej części książki podejmuja teoretyczną refleksję nad współczesną filozofia polityczną. Ich wnioski i wybór tematów sa zróżnicowane. Profesor Zbigniew Stawrowski $z$ Instytutu Studiów Politycznych Polskiej Akademii Nauk i Uniwersytetu Kardynała Stefana Wyszyńskiego, odwołując się do Arystotelesa i Platona, określa, jakie najważniejsze - jego zdaniem - pytania stawiała i stawia przed soba filozofia polityczna. Chodzi o, $z$ jednej strony, refleksje nad kształtem dobrze zorganizowanej wspólnoty politycznej, $z$ drugiej zaś - namysł nad realnymi, zachodzacymi wokół procesami i zmianami w funkcjonowaniu społeczeństw. Następnie, posługując się tym podziałem, autor przystępuje do analizy sytuacji po 1989 roku w Polsce i na świecie. Dobrze urządzone społeczeństwo - według Zbigniewa Stawrowskiego - łączy poszanowanie praw i wolności jednostek (warunek minimum wspólnego życia) z perspektywą wspólnotową, czyli koncepcja wspólnego dobra i ugruntowaniem w konkretnych wartościach. Wychodząc od takich założeń i nawiązując do myśli papieża Jana Pawła II, autor stawia bardzo krytyczną diagnozę świadomości człowieka po 1989 roku. W myśl tej interpretacji, mamy do czynienia $z$ wykorzenieniem (odejściem od uniwersalnych wartości) i dyktatura zwolenników radykalnie zinterpretowanych wolności indywidualnych. Dominujacy paradygmat, operujac hasłami wolności słowa i myśli, w rzeczywistości wprowadza coś, co można by nazwać autocenzura i ostracyzmem wobec ludzi myślących inaczej. Jest nawet mowa o współczesnej, specyficznej formie totalitaryzmu. 
Abstrahując od wniosków Zbigniewa Stawrowskiego, sugerujących jego, jak sądzę, dość konserwatywny punkt widzenia, myślę, że rozumowanie to dobrze się wpisuje w założenia omawianej konferencji. Chodziło o to, żeby skupić się na filozoficznej analizie przemian w samej filozofii i w świadomości ludzi po przemianach ustrojowych. Oczywiście nie wszyscy uczestnicy spotkania podzielali punkt widzenia Zbigniewa Stawrowskiego, choć myśliciele konserwatywni byli na tej konferencji nieco liczniej reprezentowani.

W pierwszej części publikacji znalazły się także m.in.: rozważania o tym, na czym polega obecność mitu we współczesnej filozofii politycznej (prof. Barbara Markiewicz, Uniwersytet Warszawski), opis zmiany sposobu rozumienia ideału sprawiedliwości społecznej (prof. Justyna Miklaszewska, Uniwersytet Jagielloński), refleksje dotyczace miasta (prof. Jan Kłos, Katolicki Uniwersytet Lubelski Jana Pawła II), omówienie fałszywego paradygmatu fundamentalizmu (prof. Stanisław Gałkowski, Krakowska Akademia im. Andrzeja Frycza Modrzewskiego) czy analiza możliwości filozoficznego uzasadnienia praw człowieka (Magdalena Gawin, Instytut Filozofii Uniwersytetu Warszawskiego).

Uzupełnieniem pierwszej części publikacji jest także referat specjalnego gościa konferencji, prof. Nigela Dowera $z$ Uniwersytetu $\mathrm{w}$ Aberdeen, poświęcony analizie politycznych konsekwencji kosmopolityzmu. Filozof ten zdefiniował kosmopolityzm jako koncepcję, w myśl której „wszystkie istoty ludzkie należą, w pewnym sensie, do jednej globalnej wspólnoty"2. Stąd także wynikaja pewne globalnie rozumiane obowiązki etyczne. Wyróżnił on trzy podstawowe sposoby interpretowania politycznych konsekwencji tej koncepcji. Dwa dotycza zwolenników jakiejś formy kosmopolityzmu, a trzeci, ostatni, to perspektywa osoby, która nie uważa się za kosmopolitę, ale która funkcjonując we współczesnym świecie musi liczyć się $z$ tą obecną w życiu politycznym ideą. Autor deklaruje, że jego celem było pokazanie tego, jakie sa polityczne konsekwencje upowszechnienia się tej koncepcji. Niezależnie

2 N. Dower, Polityczne konsekwencje kosmopolityzmu, w: ibidem, s. 81. 
od tego, czy jest się jej zwolennikiem, czy też nie, należy przyjąć, że jej obecność we współczesnym świecie jest faktem, a więc należy przeprowadzić analizę tego, jak będzie ona kształtować różnorodne działania i dążenia. Jakiego zachowania można się spodziewać od osoby zwiąanej $z$ jakąs forma kosmopolityzmu?

W drugiej części znalazły się artykuły związane na różne sposoby $z$ historia filozofii. Przez bezpośrednie nawiązanie do historycznych stanowisk, jak referat poświęcony myśli Lorda Actona (Karolina Jurak, doktorantka KUL) czy analizę domniemanych podstawowych założeń myśli liberalnej (prof. Zbigniew Rau, Uniwersytet Lódzki i Akademia Leona Koźmińskiego w Warszawie), po tekst prof. Jacka Bartyzela (Uniwersytet Mikołaja Kopernika w Toruniu) dotyczący tradycjonalizmu hiszpańskiego skonfrontowanego $z$ modernizmem. Czy też przez nawiąanie do najnowszej historii myśli politycznej, np. tekst prof. Macieja Chmielińskiego (Uniwersytet Łódzki) zajmujący się znaczeniem prawa w teorii publicznego wyboru, publikacja Żanety Oczkowskiej (Uniwersytet Jagielloński) dotycząca feministycznej krytyki liberalizmu czy artykuł prof. Andrzeja Szahaja (Uniwersytet Mikołaja Kopernika w Toruniu) stawiajacy pytanie o możliwość nowoczesnego konserwatyzmu. Według tego ostatniego, „nowoczesny konserwatysta” nie powinien zamykać się $\mathrm{w}$ raz ustalonych poglądach. Żyjemy $\mathrm{w}$ świecie, w którym jednolite stanowiska i jasny podział: liberał, socjalista i konserwatysta, uległ zatarciu. Należy zdać sobie $z$ tego sprawę i uwzględniać także racje innych opcji. Autor zwraca uwage na podstawowe, jego zdaniem, pojęcia i postawy kojarzone $z$ myślą konserwatywną (jak natura ludzka, niezmienność, elitaryzm, autorytet) i stara się pokazać, że nie sa one tak oczywiste, jako mogłoby się wydawać. Swój tekst kończy pytaniem o to, czy konserwatysta, który uwzględniałby te wszystkie racje, nie utraciłby swojej tożsamości.

W ostatniej części zostały umieszczone teksty zajmujące się analiza praktyki politycznej po 1989 roku i tego, jak ona kształtowała świadomość Polaków. Czytelnik może się zapoznać m.in. 
z artykułami ks. prof. Alfreda Marka Wierzbickiego (KUL), poświęconymi ewolucji etyki „Solidarności” po 1989 roku, czy dr. Jana Szomburga, przedstawiającego historię i idee zarządzanego przez niego Instytutu Badań nad Gospodarką Rynkowa z Gdańska. Tu także znalazły się teksty Soni Kamińskiej (UJ) i dr. Jakuba Szczepańskiego (UJ), a także artykuł prof. Bogdana Szlachty (UJ) dotyczący problemów współczesnych politologów konfrontujących swoje badania $z$ filozofia polityczna. W tym ostatnim tekście autor przedstawił krytykę pewnego podejścia do filozofii politycznej, rozpowszechnionego, jego zdaniem, od dawna na świecie, a w Polsce po 1989 roku. Część osób zajmujących się tą tematyką bardzo długo funkcjonowała $\mathrm{w}$ warunkach ideologizacji nauki uniemożliwiającej rzetelny namysł i badania. Po upadku PRL mieli pójść w stronę tez odrzucajacych wszelki filozoficzny namysł nad dziedziną polityki jako $z$ góry naznaczony jakąś ideologią. Filozofię polityki prof. Szlachta rozumie jako dziedzinę filozofii moralnej poszukującej „stałych" i normatywnych podstaw politycznego działania. Dzięki temu można dokonywać rozróżnień na to, co słuszne i niesłuszne $z$ moralnego punktu widzenia w dziedzinie polityki. Upraszczając nieco, można powiedzieć, że - zdaniem prof. Szlachty - współcześnie mamy do czynienia $z$ sytuacja, w której politolog (czy filozof polityki) widzi swoje zadanie w badaniu preferencji (silnie subiektywnych - takich jak emocje) poszczególnych grup tworzacych społeczeństwo oraz obserwowaniu i analizowaniu procesów zachodzących w życiu publicznym. Odżegnuje się tym samym od najważniejszego, według prof. Szlachty, zadania - poszukiwania moralnych podstaw życia politycznego i dopiero $z$ tej perspektywy dokonywania oceny podejmowanych działań. Jako dziekan Wydziału Studiów Międzynarodowych i Politycznych autor zwraca także uwage na błędy związane $z$ kształceniem studentów - przyszłych filozofów i politologów.

Jak starałem się pokazać, książka wprowadza czytelnika w bardzo ciekawa dyskusję dotyczaca przemian, które zaszły w Polsce po 1989 roku. Dotyczy to szczególnie zmian w filozofii politycznej 
w kraju i na świecie. Wszystkich autorów łączy z pewnością krytyczne podejście do sytuacji po przemianach ustrojowych. Nikt nie neguje wartości zaistniałych zmian, niemniej, co zrozumiałe, nowa sytuacja wiąże się $z$ nowymi wyzwaniami, które krytyczna refleksja powinna starać się opracować. Co warto podkreślić, nie wszyscy autorzy reprezentują te same poglądy, zróżnicowanie opinii jest spore. Zbiór otwiera tekst ks. prof. Władysława Zuziaka, rektora Uniwersytetu Papieskiego im. Jana Pawła II w Krakowie, w którym autor przez odwołanie się do chrześcijańskich ideałów nawołuje do większej solidarności. Jedna $z$ bolączek współczesności jest, w jego opinii, komercjalizacja wartości i życia ludzkiego - można przeczytać, że „nikt też nie wierzy w tzw. prawa rynku"3. W tej samej części książki, we wspomnianym wcześniej artykule, odwołuje się do pojęcia sprawiedliwości społecznej i nie jest to dla niej bynajmniej pusta kategoria. Tymczasem autor ostatniego tekstu $z$ tego działu, Piotr Biegasiewicz, zdaje się uważać, że ludzie przewodzący reformom po zmianie ustroju byli zbyt mało radykalni i tylko pełny liberalizm ekonomiczny (minimalizacja aktywności państwa) mógłby przynieść dobre rezultaty i uwolnić nas od obecnych problemów. Takie przekonanie wydaje się poparte wiara $\mathrm{w}$ istnienie obiektywnych praw wolnego rynku. To tylko jeden $z$ przykładów różnorodności sposobów myślenia autorów publikujących $\mathrm{w}$ recenzowanym zbiorze.

Mimo tego interesującego zróżnicowania można jednak powiedzieć, że reprezentacja myślicieli konserwatywnych jest nieco liczniejsza. Szkoda, że na konferencje nie zdecydowało się przyjechać więcej osób reprezentujących bardziej lewicowe stanowiska. Różnorodność i konfrontacja poglądów jest zawsze dobrą okazją do rozwoju własnych przekonań. Dlatego $z$ pewnościa warto się z nimi zapoznać za pośrednictwem tej publikacji.

Maciej Zarych

3 W. Zuziak, Etyka a myślenie o polityce, w: ibidem, s. 15.

Maciej Zarych - doktorant w Instytucie Filozofii Uniwersytetu Jagiellońskiego. 